\title{
Effects of Mefenoxam, Phosphonate, and Paclobutrazol on In Vitro Characteristics of Phytophthora cactorum and P. citricola and on Canker Size of European Beech
}

\author{
Jerry E. Weiland, United States Department of Agriculture - Agricultural Research Service, Horticultural Crops \\ Research Laboratory, Oregon State University, Department of Botany and Plant Pathology, Corvallis, OR 97331; and \\ Angela H. Nelson and George W. Hudler, Department of Plant Pathology and Plant-Microbe Biology, Cornell Uni- \\ versity, Ithaca, NY 14850
}

\begin{abstract}
Weiland, J. E., Nelson, A. H., and Hudler, G. W. 2009. Effects of mefenoxam, phosphonate, and paclobutrazol on in vitro characteristics of Phytophthora cactorum and P. citricola and on canker size of European beech. Plant Dis. 93:741-746.

Phytophthora citricola and P. cactorum cause bleeding cankers that lead to the death of mature European beech (Fagus sylvatica) in the northeastern United States. The effects of two fungicides and a plant growth regulator on in vitro pathogen characteristics and on canker expansion were investigated. In the first experiment, 16 single-spore isolates $(11$ P. citricola and 5 P. cactorum) were grown on clarified V8 juice agar amended with (i) 0 to $20 \mu \mathrm{g}$ a.i./ml of mefenoxam, (ii) 0 to $301,429 \mu \mathrm{g}$ a.i./ml phosphonate either with or without a bark-penetrating surfactant at $0.5 \mathrm{mg}$ a.i./.ml, or (iii) 0 to $25 \mathrm{mg}$ a.i./ $\mathrm{ml}$ of the surfactant alone. Radial growth, oospore production, and zoospore germination were observed to be dependent on isolate and treatment. A species effect on growth was also observed, as P. cactorum isolates were 2.5 - to sevenfold less sensitive to phosphonate, but 2- to 150 -fold more sensitive to mefenoxam than $P$. citricola isolates (based on $50 \%$ inhibition of growth). In the second experiment, bark and soil drenches of mefenoxam $(50 \mathrm{mg}$ a.i./.ml and $19 \mu \mathrm{g}$ a.i./ml, respectively), phosphonate $(301,429$ and $101 \mu \mathrm{g}$ a.i./ml, respectively), and a soil drench of paclobutrazol $(21 \mathrm{mg}$ a.i. $/ \mathrm{ml})$ were evaluated for their efficacy as curative or preventive treatments against bleeding canker. None of the treatments (curative or preventive) were able to stop canker expansion or prevent infection. However, saplings inoculated with $P$. citricola and treated with the phosphonate bark drench as either a curative or preventive treatment had cankers that were 36 to $82 \%$ shorter than those of inoculated control stems treated with water. For saplings inoculated with $P$. cactorum, the phosphonate bark drench was only effective when applied as a preventive (38\% shorter than inoculated control stems treated with water), and not as a curative treatment. No other treatment was effective at limiting canker expansion.
\end{abstract}

European beech (Fagus sylvatica) is a valuable addition to many landscapes of the northeastern United States. Its longevity, eventual mature size, and the availability of several ornamental cultivars contribute to its appeal as a dominant specimen tree in many arboreta, national parks, historic sites, college campuses, and residential neighborhoods. In contrast to the native species, American beech (Fagus grandifolia), European beech is almost exclusively limited to urban and suburban landscapes in the United States. Trees exceeding 100 years of age are common, and many serve as witness trees because of their presence during significant events in American history.

Unfortunately, mature specimen trees of European beech in the Northeast are threatened by an increasingly prevalent stem disease, bleeding canker, which is

Corresponding author: Jerry Weiland

E-mail: Jerry.Weiland@ars.usda.gov

Accepted for publication 31 March 2009.

doi:10.1094/PDIS-93-7-0741

(C) 2009 The American Phytopathological Society caused by Phytophthora citricola and $P$. cactorum $(14,17)$. Symptoms are initially apparent on the lower trunk or root flare as a cluster of small, dark spots that overlie one or more cankers. During moist or humid weather, the cankers "bleed" a characteristic red-brown fluid that stains the surface of the bark. The spots quickly coalesce over time into larger cankers that may extend for several meters up into the branches of the tree. As the cankers expand radially and begin to girdle the tree, crown symptoms manifest as sparse foliage, leaf chlorosis and wilting, and branch dieback. Eventually, the bark of older cankers sloughs off, exposing the wood, which may become decayed by saprophytic fungi. After crown symptoms appear, death may occur in as little as 1 year. Affected trees are usually in sites that otherwise seem to be favorable for beech growth because the trees in question have survived for $>100$ years and healthy trees of similar age are often growing nearby (14).

Surveys conducted by our laboratory found that the disease occurs in Connecticut, Maryland, Massachusetts, New York, and Pennsylvania, where European beech historically has been planted (17). Cankers have been found at many noteworthy locations including arboreta (Planting Fields Arboretum of Long Island, NY and the Bartlett Arboretum in North Stamford, CT), college campuses (Cornell University at Ithaca, NY and Pennsylvania State University at University Park, PA), and historic sites (Mt. Auburn Cemetery in Cambridge, MA; Vanderbilt Mansion in Hyde Park, NY; and others). The disease has been found to affect approximately $40 \%$ of the European beech population in the Northeast. At several sites, up to $50 \%$ of the trees are affected (20).

Two fungicides, mefenoxam and phosphonate, and related fungicides such as metalaxyl and fosetyl-Al have shown promise in the management of Phytophthora diseases of trees $(1,12,15)$, including those caused by $P$. citricola $(4,9,16)$ and $P$. cactorum $(4,18,19)$. Browne and Viveros (4), for example, found that preventive foliar sprays and chemigation with phosphonate inhibited canker expansion in almond trees inoculated with $P$. citricola and $P$. cactorum. They also reported that cankers were inhibited by curative topical treatments of either fosetyl-Al or mefenoxam. A third chemical, paclobutrazol, has been reported to inhibit growth of fungi pathogenic to trees in vitro (13), but has had mixed success in controlling tree diseases $(3,8)$. Paclobutrazol is a plant growth regulator that reduces shoot growth and has been purported to increase disease resistance in treated trees. Preliminary results from our laboratory indicated that the material had some fungistatic activity against both $P$. cactorum and $P$. citricola and therefore was considered a potential candidate for the treatment of cankers. The objectives of this study were to evaluate (i) the efficacy of mefenoxam and phosphonate in reducing in vitro radial growth, oospore production, and zoospore germination of $P$. cactorum and $P$. citricola, and (ii) the efficacy of both fungicides and paclobutrazol in limiting canker growth on inoculated European beech saplings.

\section{MATERIALS AND METHODS}

In vitro fungicide tests. Sixteen singlespore isolates (11 P. citricola and 5 P. cactorum) were obtained from cankers on European beech by plating $1 \times 3 \mathrm{~mm}$ bark chips from the canker margin onto PARP, a semiselective medium for Pythiaceous 
species (10). Isolates were selected from seven cities in the northeastern United States to represent the geographic range of the disease (Table 1). Inocula for radial growth, oospore production, and zoospore germination studies were produced on 20 $\mathrm{ml}$ of clarified V8 juice agar (CV8) (7 g $\mathrm{CaCO}_{3}$ mixed with $1,000 \mathrm{ml}$ of $\mathrm{V} 8$ juice, centrifuged for $20 \mathrm{~min}$ at $4,000 \mathrm{rpm}$, and the supernatant diluted 1:4 with distilled water). In both the growth and oospore production studies, 5-mm-diameter plugs of inocula were cut from the margins of 5day-old cultures and placed in the center of 84-mm-diameter plastic petri plates containing $20 \mathrm{ml}$ of CV8 amended with either mefenoxam (Subdue MAXX, 22\% a.i., Syngenta Crop Protection, Greensboro, NC: $0,0.1,1,5,10$, and $20 \mu \mathrm{g}$ a.i./ml), phosphonate (mono- and di-potassium salts of phosphorous acid, Agri-Fos 400, $45.8 \%$ a.i., Agrichem Manufacturing Industries, Loganholme, Queensland, Australia: $0,1,5,10,50,100,300,500,1,000$, $1,600,3,090$, and $301,429 \mu \mathrm{g}$ a.i./ml), or a silicone-based, bark-penetrating surfactant (Pentrabark, 99.8\% a.i., Quest Products Corp., Louisburg, KS: 0, 0.5, 2.5, 5, 10, and $25 \mathrm{mg}$ a.i./ml). An additional series of phosphonate plates that were further amended with the surfactant at $0.5 \mathrm{mg}$ a.i./ml was also included. Paclobutrazol was not included in the study because it resulted in an opaque medium that made it difficult to evaluate radial growth. Each fungicide treatment $\times$ isolate pairing was replicated three times in each of two separate trials (to provide an experimental repeat). The recommended fungicide label dose was $19 \mu \mathrm{g}$ a.i./ml for soil drenches of Subdue MAXX and 101, 1,610 to 3,220, and $301,429 \mu \mathrm{g}$ a.i./ml for soil, foliar, and bark applications of Agri-Fos 400, respectively. Plates were incubated in the dark at $21^{\circ} \mathrm{C}$. The diameter (radial growth) of each culture was calculated as the average of two measurements made after 5 days along two perpendicular axes after subtracting the initial 5-mm-diameter inoculum plug. After 30 days, the total number of oospores was counted within a $10 \times 10$ grid of $1 \mathrm{~mm}^{2}$ squares placed on the bottom center of each petri plate. Finally, pathogen transfers were attempted from two plates (one from each trial) in each isolate $\times$ fungicide treatment pairing to assay for viability. A portion of the colonized agar was excised and transferred to a fresh plate of CV8 immediately after each plate was assayed for oospore production. Each plate was incubated at room temperature (RT) for at least 4 weeks or until new growth was observed.

In the zoospore germination experiment, two 15-mm-diameter plugs were cut from the culture margin of each isolate grown on CV8 and then placed into $10 \mathrm{ml}$ of $10 \%$ sterile soil extract (SSE) water in a 60$\mathrm{mm}$-diameter glass petri plate. Plates were then incubated in the dark at RT for $12 \mathrm{~h}$, whereupon the water was decanted and replaced with another $10 \mathrm{ml}$ of SSE. After abundant sporangia had formed ( 24 to 48 h), plates were incubated at $4^{\circ} \mathrm{C}$ for $30 \mathrm{~min}$ and then brought to RT for $30 \mathrm{~min}$ to induce zoospore release. The zoospore concentration was estimated using a hemacytometer and adjusted to 10,000 zoospores $/ \mathrm{ml}$. Four milliliters of the spore suspension was then transferred to another 60-mm-diameter glass petri plate containing a $4 \mathrm{ml}, 2 \times$ solution of each fungicide concentration listed above and then mixed for a final $1 \times$ fungicide concentration. After zoospore encystment and attachment were complete ( 4 to $12 \mathrm{~h}$ ), the liquid was decanted and replaced with the appropriate $1 \times$ concentration of fungicide in clarified V8 juice broth (to produce robust hyphae), incubated at RT for an additional $4 \mathrm{~h}$, and then incubated at $4^{\circ} \mathrm{C}$ until evaluation for germination could take place (within $12 \mathrm{~h}$ ). One hundred encysted zoospores from each plate were counted, and germination was considered to have occurred if the germ tube length was twice the diameter of the encysted zoospore. Each fungicide treatment $x$ isolate pairing was replicated three times in each of two separate trials (to provide an experimental repeat).

Data were analyzed by one-way and two-way analyses of variance (ANOVA) for effects of trial, isolate, pathogen species, and fungicide concentration. Zoospore germination data were converted into proportions and transformed by the arcsine of the square root to homogenize variance before analyses. If trial effects were detected, subsequent analyses also were conducted for each trial separately. Because no one transformation was able to linearize all isolate $\times$ treatment pairings within each test (growth, oospore production, and zoospore germination), the concentration required for $50 \%$ inhibition of growth $\left(\mathrm{EC}_{50}\right.$ value), oospore production, and zoospore germination was estimated by plotting the percent inhibition (compared to controls) versus fungicide concentration. Relationships among growth, oospore production, and zoospore germination were examined by calculating Pearson correlation coefficients. Analyses were performed using Minitab Statistical Software (release 15.1; Minitab Inc., State College, PA).

Curative treatment experiment. In 2006, 168 1-m-tall, 1- to 2-cm-diameter

Table 1. Fungicide sensitivity of Phytophthora citricola and P. cactorum isolates to phosphonate, phosphonate + surfactant, surfactant, and mefenoxam

\begin{tabular}{|c|c|c|c|c|c|c|c|c|c|c|c|c|c|}
\hline \multirow[b]{2}{*}{ Isolate (sp. $\left.{ }^{w}\right)$} & \multirow[b]{2}{*}{ Location $^{x}$} & \multicolumn{4}{|c|}{ Growth $\mathrm{EC}_{50}{ }^{\mathrm{y}}$} & \multicolumn{4}{|c|}{ Oospore $\mathrm{EC}_{50}$} & \multicolumn{4}{|c|}{ Zoospore EC E0 $_{50}$} \\
\hline & & $\mathbf{P z}^{\mathbf{z}}$ & $\mathbf{P}+\mathbf{S}$ & $\mathbf{S}$ & $\mathbf{M}$ & $\mathbf{P}$ & $\mathbf{P}+\mathbf{S}$ & $\mathbf{S}$ & M & $\mathbf{P}$ & $\mathbf{P}+\mathbf{S}$ & $\mathbf{S}$ & $\mathbf{M}$ \\
\hline 01-04a (ci) & Rochester, NY & 41 & 32 & 26 & 0.6 & 16 & 0.7 & 0.4 & 0.3 & 2,214 & 2,030 & 8.0 & - \\
\hline 01-05a (ci) & Annapolis, MD & 44 & 26 & 26 & 1.0 & 300 & 147 & 13.0 & 4.0 & 813 & 1,013 & - & - \\
\hline 02-04a (ci) & Rochester, NY & 40 & 25 & 28 & 0.7 & 35 & 0.1 & 0.3 & 1.0 & 3,790 & 35 & - & - \\
\hline 04-05a (ci) & Oyster Bay, NY & 65 & 35 & 30 & 1.3 & 280 & 59 & 6.0 & 3.0 & 329 & 52 & 0.4 & - \\
\hline 06-04a (ci) & Albany, NY & 36 & 36 & 38 & 0.4 & 31 & 0.6 & 0.3 & 0.4 & 2,740 & 2,185 & - & - \\
\hline 09-04a (ci) & Ithaca, NY & 67 & 61 & 42 & 1.0 & 40 & 0.7 & 0.5 & 0.9 & 2,571 & 2,184 & 0.3 & - \\
\hline $10-04 a(\mathrm{ci})$ & State College, PA & 45 & 14 & 17 & 0.7 & 53 & 0.7 & 0.5 & 0.5 & 1,193 & 2,170 & 0.3 & 22 \\
\hline 13-04a (ci) & Ithaca, NY & 41 & 29 & 30 & 0.8 & 330 & 0.6 & 0.4 & 1.0 & 1,992 & 0.5 & 0.3 & - \\
\hline 14-04a (ci) & Ithaca, NY & 38 & 24 & 25 & 0.7 & 38 & 0.8 & 11.0 & 0.9 & 837 & 1,852 & - & - \\
\hline 23-04a (ci) & Cambridge, MA & 34 & 26 & 27 & 0.7 & 23 & 0.7 & 0.4 & 0.8 & 2,371 & 2,134 & - & - \\
\hline 37-04a (ci) & Ithaca, NY & 47 & 8 & 50 & 3.0 & 84 & 10 & 1.0 & 0.08 & 54,811 & 2,256 & - & - \\
\hline 03-04a (ca) & Rochester, NY & 206 & 117 & - & 0.2 & 75 & 0.8 & 18.0 & 0.05 & 67,000 & 2,150 & - & - \\
\hline 04-04a (ca) & Rochester, NY & 238 & 89 & - & 0.07 & 123 & 179 & - & 0.07 & 160,000 & 0.5 & 0.3 & - \\
\hline 05-04a (ca) & Albany, NY & 218 & 143 & - & 0.06 & 223 & 75 & 4.6 & 1.5 & 360 & 1,697 & - & - \\
\hline 08-04a (ca) & Ithaca, NY & 196 & 85 & - & 0.02 & 9 & 18 & 8.0 & 0.05 & 296 & 0.5 & 0.3 & 19 \\
\hline 20-04a (ca) & Cambridge, MA & 166 & 82 & - & 0.08 & 243 & 59 & - & - & 2,409 & 0.7 & 0.4 & 13 \\
\hline
\end{tabular}

${ }^{\mathrm{w}}$ Phytophthora species tested: $\mathrm{ci}=P$. citricola, $\mathrm{ca}=P$. cactorum. Isolates in bold were used in the curative and preventive treatment experiments.

${ }^{x}$ Geographic location of cankered tree from which each isolate was obtained.

${ }^{\mathrm{y}} \mathrm{EC}_{50}$ is the concentration of fungicide required for $50 \%$ inhibition of the parameter tested (radial growth, oospore production, or zoospore germination). Values in units of $\mu \mathrm{g}$ a.i./ml (phosphonate and mefenoxam) or $\mathrm{mg}$ a.i./ml (surfactant). - indicates that the $\mathrm{EC}_{50}$ value could not be estimated from the data collected because there was either no effect or a stimulatory effect of the fungicide or surfactant on the parameter tested.

${ }^{\mathrm{z}}$ Fungicide or adjuvant treatment series: $\mathrm{P}=$ phosphonate at $0,1,5,10,50,100,300,500,1,000,1,600,3,090$, and 301,429 $\mu \mathrm{g}$ a.i./ml; $\mathrm{P}+\mathrm{S}=$ same series as $\mathrm{P}$, but amended with $0.5 \mathrm{mg}$ a.i./ml of a silicone-based, bark-penetrating surfactant; $\mathrm{S}=$ surfactant at $0,0.5,2.5,5,10$, and $25 \mathrm{mg}$ a.i./ml; and $\mathrm{M}=\mathrm{me}-$ fenoxam at $0,0.1,1,5,10$, and $20 \mu \mathrm{g}$ a.i./ml. $n=6$. 
European beech saplings were potted into 8-liter pots with 50\% Cornell soilless mix (equal parts peat and vermiculite with nitrogen, phosphorous, and potassium added at the rate of $0.4 \mathrm{~kg} / \mathrm{m}^{3}$ ) and $50 \%$ Agway topsoil (Scotts Company, Lebanon, CT). Trees were separated into two groups (trials) of 84 and each group placed according to a completely randomized design (CRD) into separate cold frames (to provide an experimental repeat). All subsequent inoculation and fungicide treatments were prepared and applied to each trial on separate dates. Inocula were produced from a single zoospore isolate each of $P$. cactorum (08-04a) and P. citricola (1404a) originally obtained in 2004 from active cankers on European beech on the Cornell University campus in Ithaca, NY. Local isolates were selected to minimize the chance for accidental introduction and establishment of nonlocal isolates. Preliminary studies indicated that the amount of necrosis caused by each isolate on seedling European beech was representative of that observed among other canker isolates of the same species (21). Inocula for each isolate were grown on $20 \mathrm{ml}$ of CV8 in an 84-mm-diameter petri plate in the dark for 5 days at RT. Inoculum plugs $(5 \mathrm{~mm}$ diameter) were then cut from the culture margin and used to inoculate the main stem of each sapling approximately $0.7 \mathrm{~m}$ above the soil line. Half of the trees in each trial were inoculated with $P$. cactorum, and the remaining 42 trees with $P$. citricola. Each stem was inoculated by excising a $5 \mathrm{~mm}^{2}$ flap of bark and placing a plug of inoculum on the resulting wound with the mycelium side toward the stem. The inoculum plug was held in place using Parafilm (Pechiney Plastic Packaging, Chicago, IL), which was removed 2 weeks later. Inoculations were conducted in mid-June.

One month after inoculation, one of six treatments was applied to each sapling as a (i) water bark drench (control), (ii) mefenoxam bark drench $(50 \mathrm{mg}$ a.i./ml), (iii) 330-ml mefenoxam soil drench (19 $\mu \mathrm{g}$ a.i./ml), (iv) phosphonate bark drench (301,429 $\mu \mathrm{g}$ a.i./ml), (v) 330-ml phosphonate soil drench $(101 \mu \mathrm{g}$ a.i./ml), and (vi) 600-ml paclobutrazol soil drench $(21 \mathrm{mg}$ a.i./ml, as Cambistat 2SC, $22.3 \%$ a.i., Rainbow Treecare Scientific Advancements, St. Louis Park, MN). The bark treatment with phosphonate was further amended with the bark penetrating surfactant at $26 \mathrm{mg}$ a.i./ml. Bark drenches were applied only to the stem segment containing each canker and extending $2 \mathrm{~cm}$ beyond the upper and lower canker margin. All treatments were applied as recommended by the respective product label except for the mefenoxam bark drench, for which Subdue MAXX is not currently registered. The mefenoxam bark drench rate used in the present study $(50 \mathrm{mg}$ a.i./ml) was modified to be slightly greater than that used by Browne and Viveros (37 $\mathrm{mg}$ a.i./ml) for topical application on almond trees inoculated with $P$. cactorum and P. citricola (4).

Canker length in millimeters was measured from the lower margin of the inoculation point to the lowest point of the canker margin at 1 and 12 months after inoculation. The entire length of the canker, from the upper to the lower canker margin, was not measured because in some cases the stem was completely girdled, and the death of the upper stem prevented an accurate assessment of the entire canker length. In cases where the canker margin was obscured by callus (at 12 months only), the callus was gently cut away until the margin between necrotic and living tissue was visible. Fourteen months after inoculation (mid-August 2007), the bark overlying each completely or incompletely healed canker was excised and the necrotic tissue underneath was sampled to determine whether treatments affected Phytophthora presence and/or viability. A $2 \times$ $2 \times 4 \mathrm{~mm}$ chip of bark was removed, and half was plated on PARP and half subjected to analysis with a Phytophthora ELISA test kit (Phytophthora PathoScreen kit PSA 92600, Agdia Inc., Elkhart, IN). The ELISA test kit was used as a second method, independent of viability, to determine whether Phytophthora was still present.

Preventive treatment experiment. In September 2007, each of the six treatments used in the curative treatment experiment (with the exception of paclobutrazol) were reapplied to the same saplings. Saplings were healthy in appearance with approximately $0.7 \mathrm{~m}$ of main stem (including living branches and leaves) remaining below the 2006 inoculation point. The existence of the two trials (experimental repeat) and CRD from 2006 were maintained, and materials for each trial were prepared and applied independently on separate dates. Bark drenches were applied to a $5-\mathrm{cm}$ length of bark that encircled a portion of the main stem located at least $10 \mathrm{~cm}$ from the portion treated in 2006. Trees originally treated with paclobutrazol in 2006 were not treated again in 2007 because of the long-acting nature of the compound (as evidenced by the presence of dark green, distorted leaves and shortened stem internodes) and because label instructions recommend 3 years between applications. Inocula of $P$. cactorum isolate $08-04 \mathrm{a}$ and $P$. citricola isolate $14-04$ a were produced as described previously, and the same inoculation technique was used to infect trees 2 weeks after fungicide application. Saplings were inoculated approximately 15 to $50 \mathrm{~cm}$ from the soil surface. Canker length in millimeters was measured from the lower margin of the inoculation point to the lowest point of the canker margin at 1 and 10 months after inoculation.

Data from both the curative treatment experiment and the preventive treatment experiment were analyzed by one-way and two-way ANOVA for effects of trial, isolate, and treatment. If trial effects were detected, subsequent analyses also were conducted for each trial separately. In addition, the 2007 preventive treatment experiment was tested for an effect of the 2006 curative treatment experiment by setting the 2006 data as a covariate in an analysis of covariance (ANCOVA) of the 2007 data. Data on the frequency of isolation on PARP and the frequency of detection by ELISA from the curative treatment experiment were analyzed by the chisquare test of independence. Pairwise comparisons for effect of treatment were conducted using Fisher's least significant difference procedure $(P=0.05)$. Analyses were performed using Minitab Statistical Software (release 15.1; Minitab Inc.).

\section{RESULTS}

In vitro fungicide tests. Radial growth on control plates (no fungicide amendment) ranged from 37 to $53 \mathrm{~mm}$ for $P$. cactorum isolates (pooled mean for all isolates $=47 \mathrm{~mm}$ ) and from 49 to $74 \mathrm{~mm}$ for $P$. citricola isolates (pooled mean for all isolates $=62 \mathrm{~mm}$ ). One-way ANOVA on data from the control plates indicated an effect of species $(P<0.001)$ on growth with $P$. cactorum isolates generally growing more slowly than $P$. citricola isolates. Two-way ANOVA indicated an effect of trial $(P<0.001)$, isolate $(P<0.001)$, and treatment $(P<0.001)$. Results were similar for analyses of trial 1 and 2 data separately; therefore, $\mathrm{EC}_{50}$ values from the pooled data set are presented (Table 1). Each series of treatments (phosphonate, phosphonate + surfactant, surfactant, and mefenoxam) caused a logarithmic decrease in growth in response to each increasing treatment concentration. However, four of the $P$. cactorum isolates $(03-04 \mathrm{a}, 04-04 \mathrm{a}$, 05-04a, and 20-04a) showed a small initial decrease and then a subsequent increase in growth (equal to or greater than the corresponding control treatment diameter) in response to an increasing concentration of the surfactant alone. $\mathrm{EC}_{50}$ values ranged from 166 to $238 \mu \mathrm{g}$ a.i./ml for $P$. cactorum isolates treated with phosphonate alone, which was 2.5- to sevenfold greater (less sensitive) than $P$. citricola isolates (34 to $67 \mu \mathrm{g}$ a.i./ml) (Table 1). On phosphonate plates amended with the surfactant, $\mathrm{EC}_{50}$ values for $P$. cactorum and $P$. citricola were generally less than those with phosphonate alone ( 8 to 61 and 82 to $143 \mu \mathrm{g}$ a.i./ml, respectively), with $\mathrm{EC}_{50}$ values 1.5 to 18 -fold greater for $P$. cactorum isolates than for $P$. citricola isolates. $\mathrm{EC}_{50}$ values could not be estimated for $P$. cactorum isolates tested on an increasing concentration of surfactant because the estimated $\mathrm{EC}_{50}$ values were much greater than the concentration of the surfactant tested. However, for $P$. citricola, $\mathrm{EC}_{50}$ values ranged from 17 to $50 \mathrm{mg}$ a.i./ml. $\mathrm{EC}_{50}$ 
values for the mefenoxam series ranged from 0.02 to $0.2 \mu \mathrm{g}$ a.i./ml for P. cactorum, which was 2- to 150 -fold less (more sensitive) than $P$. citricola isolates ( 0.4 to $3.0 \mu \mathrm{g}$ a.i./ml). All attempts to culture the pathogen from each isolate $\times$ treatment pairing were successful, indicating viability, except for those at the highest level of phosphonate $(301,429 \mu \mathrm{g}$ a.i./ml).

Oospore counts on control plates ranged from 12 to 21 oospores per $\mathrm{mm}^{2}$ for $P$. cactorum isolates (pooled mean for all isolates $=15$ oospores per $\mathrm{mm}^{2}$ ) and from eight to 19 oospores per $\mathrm{mm}^{2}$ for $P$. citricola isolates (pooled mean for all isolates $=15$ oospores per $\mathrm{mm}^{2}$ ). One-way ANOVA indicated no effect of species $(P=$ $0.367)$ on the number of oospores produced per $\mathrm{mm}^{2}$. Two-way ANOVA indicated an effect of trial $(P=0.033)$, isolate $(P<0.001)$, and treatment $(P<0.001)$. Results were similar for analyses of trial 1 and 2 data separately; therefore, $\mathrm{EC}_{50}$ values from the pooled data set are presented (Table 1). Each series of treatments generally displayed a logarithmic decrease in oospore numbers in response to each increasing treatment concentration. In general, $\mathrm{EC}_{50}$ values for oospore production were similar for both $P$. cactorum and $P$. citricola isolates within each treatment series. No correlation was observed between $\mathrm{EC}_{50}$ values for radial growth and oospore production among $P$. cactorum or $P$. citricola isolates $(P \geq 0.140$ and $P \geq$ 0.324 , respectively).

Zoospore germination in control plates ranged from 61 to $92 \%$ for $P$. cactorum isolates (pooled mean for all isolates = $76 \%$ ) and from 79 to $99 \%$ for P. citricola isolates (pooled mean for all isolates = $92 \%)$. One-way analysis of variance indicated an effect of species $(P<0.001)$ on germination, with $P$. citricola isolates generally showing greater germination percentages than $P$. cactorum isolates. Twoway ANOVA indicated an effect of isolate $(P<0.001)$ and treatment $(P<0.001)$, but not of trial $(P=0.296)$. Therefore, $\mathrm{EC}_{50}$ values from the pooled data set are presented (Table 1). Each series of treatments generally displayed a nonlinear (but not logarithmic) decrease in percent germination in response to each increasing treatment concentration. However, zoospore germination was either stimulated or unaffected by an increasing concentration of surfactant for seven isolates. Likewise, germination was largely unaffected by an increasing concentration of mefenoxam. As a consequence, $\mathrm{EC}_{50}$ values for these isolates (with germination either stimulated or unaffected by the surfactant or mefenoxam) could not be estimated and are not represented in Table $1 . \mathrm{EC}_{50}$ values for zoospore germination were similar for both $P$. cactorum and $P$. citricola isolates within each treatment series. No correlation was observed between $\mathrm{EC}_{50}$ values for radial growth or oospore production and zoospore germination for $P$. cactorum $(P \geq$ 0.056). However, zoospore germination of P. citricola isolates on phosphonate plates was positively correlated with growth on surfactant-only plates and on mefenoxam plates $(r=0.711, P=0.014$ and $r=0.928$, $P<0.001$, respectively). In addition, zoospore germination on phosphonate + surfactant plates was positively correlated to oospore production on plates containing only phosphonate $(r=0.699, P=0.011)$ for $P$. citricola isolates. No other correlations were observed among $P$. citricola isolates $(P \geq 0.090)$.

Curative treatment experiment. All saplings inoculated with either Phy-

Table 2. Effect of paclobutrazol, mefenoxam, and phosphonate curative treatments ${ }^{\mathrm{w}}$ on canker length and pathogen detection in European beech saplings inoculated with Phytophthora cactorum or P. citricola 12 months after treatment

\begin{tabular}{llccccc}
\hline Isolate & Treatment $^{\mathbf{x}}$ & $\begin{array}{c}\text { Mean canker } \\
\text { length }(\mathbf{m m})\end{array}$ & $\begin{array}{c}\text { Range } \\
(\mathbf{m m})\end{array}$ & SE & Culture $^{\mathbf{y}}$ & ELISA $^{\mathbf{z}}$ \\
\hline P. cactorum & Control & $12 \mathrm{ab}$ & $4-25$ & 1.600 & $1 / 14$ & $13 / 14$ \\
(08-04a) & Paclobutrazol & $13 \mathrm{~b}$ & $3-27$ & 1.540 & $0 / 14$ & $13 / 14$ \\
& Mef.-bark & $9 \mathrm{a}$ & $3-14$ & 0.894 & $1 / 14$ & $13 / 14$ \\
& Mef.-soil & $10 \mathrm{ab}$ & $5-18$ & 0.917 & $3 / 14$ & $14 / 14$ \\
& Phos.-bark & $12 \mathrm{ab}$ & $3-24$ & 1.73 & $2 / 14$ & $12 / 14$ \\
& Phos.-soil & $12 \mathrm{ab}$ & $3-23$ & 1.40 & $2 / 14$ & $14 / 14$ \\
P. citricola & Control & $42 \mathrm{bc}$ & $12-115$ & 5.32 & $4 / 14$ & $13 / 14$ \\
(14-04a) & Paclobutrazol & $42 \mathrm{bc}$ & $13-81$ & 4.02 & $1 / 14$ & $14 / 14$ \\
& Mef.-bark & $45 \mathrm{c}$ & $12-140$ & 7.39 & $3 / 14$ & $13 / 14$ \\
& Mef.-soil & $34 \mathrm{abc}$ & $7-71$ & 3.58 & $0 / 14$ & $11 / 14$ \\
& Phos.-bark & $27 \mathrm{a}$ & $13-49$ & 2.13 & $1 / 14$ & $10 / 14$ \\
& Phos.-soil & $30 \mathrm{ab}$ & $15-48$ & 1.71 & $4 / 14$ & $13 / 14$ \\
\hline
\end{tabular}

${ }^{\mathrm{w}}$ Curative treatments were applied 1 month after inoculation.

${ }^{\mathrm{x}}$ Fungicide and plant growth regulator treatments applied to European beech saplings inoculated with either $P$. cactorum or $P$. citricola: Control $=$ water control; Paclobutrazol $=600 \mathrm{ml}$ paclobutrazol soil drench at $21 \mathrm{mg}$ a.i. $/ \mathrm{ml}$; Mef.-bark = mefenoxam bark drench at $50 \mathrm{mg}$ a.i. $/ \mathrm{ml}$; Mef.-soil $=330 \mathrm{ml}$ mefenoxam soil drench at $19 \mu \mathrm{g}$ a.i./ml; Phos.-bark = phosphonate bark drench at 301,429 $\mu \mathrm{g}$ a.i. $/ \mathrm{ml}$; and Phos. soil $=330 \mathrm{ml}$ phosphonate soil drench at $101 \mu \mathrm{g}$ a.i. $/ \mathrm{ml} . n=14$.

${ }^{y}$ Number of successful isolations on PARP medium from cankers 14 months after inoculation. $n=14$.

${ }^{\mathrm{z}}$ Number of successful detection attempts from cankers with a Phytophthora ELISA detection kit 14 months after inoculation. $n=14$. tophthora isolate developed a canker in response to inoculation. Cankers were visible within the first 2 weeks of inoculation and appeared as dark depressions on the stem. Occasionally, bleeding was observed from the cankers (approximately $10 \%$ of inoculated saplings), but this had dried by late July. Callus production began within 2 months after inoculation at the juncture between necrotic and living tissues, and many of the nongirdling cankers were completely healed within 1 year. No effect of treatment was observed on either callus production or healing.

Cankers caused by $P$. cactorum isolate 08-04a were always shorter than those caused by $P$. citricola isolate 14-04a at 1 month after inoculation $(11 \mathrm{~mm}$ versus 41 $\mathrm{mm}$, respectively, in inoculated control stems treated with water). Although some cankers continued to expand, mean canker lengths on control stems were similar for the two isolates 11 months later $(12 \mathrm{~mm}$ and $42 \mathrm{~mm}$, respectively). Therefore, only data from the second time period are shown (Table 2). Forty percent of the saplings inoculated with $P$. citricola were girdled within 1 month after inoculation, while none of the trees inoculated with $P$. cactorum were ever girdled. Two-way ANOVA indicated an effect of trial $(P<$ $0.001)$, isolate $(P<0.001)$, and treatment $(P=0.035)$ on canker length. The difference in mean canker length between trials was minimal (approximately $5 \mathrm{~mm}$ and 12 $\mathrm{mm}$ greater in trial 1 than in trial 2 for $P$. cactorum- and $P$. citricola-inoculated saplings, respectively) and might be explained by the later date of inoculation of trees in trial 2. Results were similar for analyses of trial 1 and 2 data separately; therefore pooled data are presented (Table 2). One-way ANOVA with Fisher's LSD $(P=0.05)$ found that none of the treatments were effective at reducing or halting canker expansion in stems inoculated with $P$. cactorum $(P \geq 0.254)$. Only stems inoculated with $P$. citricola and then treated with the phosphonate bark drench produced cankers that were significantly shorter $(36 \%)$ than control stems treated with water (27 and $42 \mathrm{~mm}$, respectively) $(P=0.024)$.

$P$. cactorum and $P$. citricola were reisolated infrequently from saplings 14 months after inoculation (Table 2). Only $13 \%(22 / 168)$ of the saplings inoculated in both trials yielded cultures of Phytophthora. Chi-square analysis indicated that the frequency of pathogen isolation from the stems was independent of treatment $(P \geq 0.151)$ and isolate $(P \geq 0.067)$. In contrast, $91 \%(153 / 168)$ of the saplings inoculated in both trials were positive for the presence of Phytophthora when tested with the ELISA test kit (Table 2). Chisquare analysis indicated that frequency of detection via ELISA was also independent of treatment $(P \geq 0.172)$ and isolate $(P \geq 0.067)$. 
Preventive treatment experiment. All saplings inoculated with either Phytophthora isolate developed a canker in response to inoculation regardless of treatment. Cankers were visible within the first 2 weeks of inoculation and were similar in appearance to those described in the curative treatment experiment.

As observed previously, cankers caused by $P$. cactorum isolate $08-04$ a were always shorter than those caused by $P$. citricola isolate 14-04a at 1 month after inoculation ( $8 \mathrm{~mm}$ versus $33 \mathrm{~mm}$, respectively, in inoculated control stems treated with water) (Table 3). Although most cankers continued to expand, this difference was still apparent 10 months after inoculation (20 $\mathrm{mm}$ versus $34 \mathrm{~mm}$, respectively). A majority of the saplings (62\%) inoculated with $P$. citricola were girdled within 1 month after inoculation, while none of the trees inoculated with $P$. cactorum were ever girdled. Analysis of covariance found no effect of the 2006 experiment on the 2007 experiment $(P=0.647)$. Two-way ANOVA indicated that there was an effect of isolate $(P$ $<0.001)$ and treatment $(P<0.001)$, but not of trial $P=0.680)$ on canker length. Oneway ANOVA with Fisher's LSD $(P=0.05)$ indicated that only stems treated with the phosphonate bark drench treatment and then inoculated with either isolate $P$. $c a c$ torum $08-04$ a or $P$. citricola $14-04$ a produced cankers significantly shorter than inoculated control stems treated with water $(P \leq 0.044)$. This effect was observed at both 1 and 10 months after inoculation $(P$ $\leq 0.044)$. Cankers from trees treated with the phosphonate bark drench and then inoculated with $P$. cactorum isolate $08-04$ a were $38 \%$ ( 1 month) and $60 \%$ (10 months) shorter than those from inoculated control trees. Cankers from trees treated with the phosphonate bark drench and then inoculated with $P$. citricola isolate 14-04a were $82 \%$ (1 month) and 53\% (10 months) shorter than those from inoculated control trees. No other treatment was significantly different from control stems treated with water $(P \geq 0.05)$.

\section{DISCUSSION}

The mefenoxam $\mathrm{EC}_{50}$ values for $P$. citricola growth in the present study are similar to those of other $P$. citricola isolates tested on metalaxyl, a racemic mixture that includes mefenoxam as an enantiomer $(5,7,11)$. For example, the metalaxyl $\mathrm{EC}_{50}$ values for the growth of 12 out of the $13 P$. citricola isolates from soil and woody ornamentals tested by Ferrin and Kabashima (11) ranged from 0.087 to $4.970 \mu \mathrm{g}$ a.i./ml, which was similar to the range reported in this study $(0.4$ to $3.0 \mu \mathrm{g}$ a.i./ml). Likewise, the mefenoxam $\mathrm{EC}_{50}$ values for $P$. cactorum isolates from the present study were similar to those from another study measuring $P$. cactorum growth on mefenoxam (2). In contrast, the concentration of phosphonate required to reduce $P$. citricola growth by $50 \%$ in the present study (34 to $67 \mu \mathrm{g}$ a.i./ml) was much greater than that reported by Coffey and Joseph (6) in a test of three P. citricola isolates from avocado (1.3 to $1.7 \mu \mathrm{g}$ a.i./ml). Differences among isolates by host or geographic location may partially explain these differences.

Although all isolates of $P$. cactorum and $P$. citricola tested in the in vitro assay were more sensitive to mefenoxam than phosphonate, mefenoxam was not effective at limiting canker expansion by either pathogen. This is in contrast to results reported by Browne and Viveros (4), where topical application of mefenoxam at $37 \mathrm{mg}$ a.i. $/ \mathrm{ml}$ to almond trees inoculated with either $P$. cactorum or $P$. citricola reduced canker expansion by approximately 80 and $50 \%$, respectively. The doses used in both the mefenoxam bark and soil drench treatments from the present study $(50 \mathrm{mg}$ a.i./ml and $19 \mu \mathrm{g}$ a.i./ml, respectively) seem adequate given that both are greater than the estimated $\mathrm{EC}_{50}$ values for all 16 isolates $\left(\mathrm{EC}_{50} \leq 3 \mu \mathrm{g}\right.$ a.i. $\left./ \mathrm{ml}\right)$. However, the methods used may have been inadequate to deliver a therapeutic dose. Fungicide uptake might have been enhanced by the use of preparatory bark cuts (4) with the bark drench treatments, or by a spring application (rather than midsummer to early autumn) of the soil drench treatments to maximize root uptake of the fungicide.

Evidence from both the in vitro and sapling experiments indicates that pathogen identity is an important consideration for disease management. The curative and preventive applications of the phosphonate bark drench treatment were usually less effective (or ineffective) at limiting expansion of cankers caused by $P$. cactorum. This might be related to the greater sensitivity of $P$. citricola isolates to phosphonate as observed from the $\mathrm{EC}_{50}$ values from in vitro radial growth. Although the phosphonate soil drench was ineffective at limiting cankers caused by either isolate, it should be noted that the recommended dose of the phosphonate soil drench (101 $\mu \mathrm{g}$ a.i./ml) was approximately twice the observed $\mathrm{EC}_{50}$ values for isolates of $P$. citricola (34 to $67 \mu \mathrm{g}$ a.i./ml), but only about half of the observed $\mathrm{EC}_{50}$ values for isolates of $P$. cactorum (166 to $238 \mu \mathrm{g}$ a.i./ml). A spring application of the phosphonate soil drench might enhance root uptake of the fungicide, but the current label rate will probably not result in an effective dose for cankers caused by $P$. cactorum. Pathogen identity seems to be particularly significant given that tree care professionals have had mixed reviews about the efficacy of phosphonate bark drenches at treating mature, cankered European beech. In some cases, cankers grew more slowly or trees were apparently cured. In other cases, canker expansion continued unabated. An assessment of pathogen identity prior to treatment may have helped explain why some of these treatments failed. In addition, preliminary tests by our laboratory on mature cankered beech trees with the phosphonate bark drench have been promising (data not shown). However, pathogen identity was not assessed prior to treatment. In the future, isolation and identification of the causal Phytophthora species before fungicide application will help clarify the importance of pathogen identity in management of the disease.

Results presented here indicate that a bark drench of phosphonate can effectively limit expansion of cankers caused by $P$. citricola in European beech saplings and may prove effective for cankers caused by $P$. cactorum if a higher dose is used. Future studies should continue to compare alternate fungicide chemistries, doses, and the

Table 3. Effect of paclobutrazol, mefenoxam, and phosphonate preventive treatments ${ }^{y}$ on canker length of European beech saplings inoculated with Phytophthora cactorum or P. citricola, 1 and 10 months after inoculation

\begin{tabular}{|c|c|c|c|c|c|c|c|}
\hline \multirow[b]{2}{*}{ Isolate } & \multirow[b]{2}{*}{ Treatment $^{\mathrm{z}}$} & \multicolumn{3}{|c|}{1 Month after inoculation } & \multicolumn{3}{|c|}{10 Months after inoculation } \\
\hline & & $\begin{array}{l}\text { Mean canker } \\
\text { length }(\mathrm{mm})\end{array}$ & $\begin{array}{l}\text { Range } \\
(\mathbf{m m})\end{array}$ & SE & $\begin{array}{l}\text { Mean canker } \\
\text { length }(\mathbf{m m})\end{array}$ & $\begin{array}{l}\text { Range } \\
(\mathbf{m m})\end{array}$ & SE \\
\hline $\begin{array}{l}\text { P. cactorum } \\
\text { (08-04a) }\end{array}$ & $\begin{array}{l}\text { Control } \\
\text { Paclobutrazol } \\
\text { Mef.-bark } \\
\text { Mef.-soil } \\
\text { Phos.-bark } \\
\text { Phos.-soil }\end{array}$ & $\begin{array}{l}8 \mathrm{c} \\
7 \mathrm{abc} \\
7 \mathrm{abc} \\
6 \mathrm{ab} \\
5 \mathrm{a} \\
8 \mathrm{bc}\end{array}$ & $\begin{array}{l}5-19 \\
3-11 \\
4-10 \\
4-15 \\
4-10 \\
4-18\end{array}$ & $\begin{array}{l}0.856 \\
0.578 \\
0.488 \\
0.823 \\
0.406 \\
0.953\end{array}$ & $\begin{array}{l}20 \mathrm{~b} \\
15 \mathrm{ab} \\
13 \mathrm{ab} \\
16 \mathrm{~b} \\
8 \mathrm{a} \\
18 \mathrm{~b}\end{array}$ & $\begin{array}{l}8-66 \\
5-30 \\
6-35 \\
5-40 \\
2-21 \\
8-41\end{array}$ & $\begin{array}{l}4.03 \\
1.94 \\
2.02 \\
2.64 \\
1.16 \\
2.83\end{array}$ \\
\hline $\begin{array}{l}\text { P. citricola } \\
(14-04 a)\end{array}$ & $\begin{array}{l}\text { Control } \\
\text { Paclobutrazol } \\
\text { Mef.-bark } \\
\text { Mef.-soil } \\
\text { Phos.-bark } \\
\text { Phos.-soil }\end{array}$ & $\begin{array}{l}33 \mathrm{bc} \\
26 \mathrm{~b} \\
31 \mathrm{bc} \\
34 \mathrm{c} \\
6 \mathrm{a} \\
30 \mathrm{bc}\end{array}$ & $\begin{array}{r}21-58 \\
13-43 \\
7-60 \\
16-58 \\
3-14 \\
19-48\end{array}$ & $\begin{array}{l}2.59 \\
2.42 \\
3.38 \\
3.27 \\
0.790 \\
2.53\end{array}$ & $\begin{array}{l}34 \mathrm{~b} \\
35 \mathrm{~b} \\
40 \mathrm{~b} \\
39 \mathrm{~b} \\
16 \mathrm{a} \\
36 \mathrm{~b}\end{array}$ & $\begin{array}{c}19-70 \\
18-74 \\
7-115 \\
19-85 \\
5-75 \\
15-70\end{array}$ & $\begin{array}{l}3.39 \\
3.81 \\
6.79 \\
5.01 \\
4.81 \\
4.39\end{array}$ \\
\hline
\end{tabular}

y Preventive treatments were applied 2 weeks prior to inoculation.

${ }^{\mathrm{z}}$ Fungicide and plant growth regulator treatments applied to European beech saplings prior to inoculation with either $P$. cactorum or $P$. citricola: Control $=$ water control; Paclobutrazol $=600 \mathrm{ml}$ paclobutrazol soil drench at $21 \mathrm{mg}$ a.i./ml; Mef.-bark = mefenoxam bark drench at $50 \mathrm{mg}$ a.i./ml; Mef.-soil $=330 \mathrm{ml}$ mefenoxam soil drench at $19 \mu \mathrm{g}$ a.i./ml; Phos.-bark = phosphonate bark drench at 301,429 $\mu \mathrm{g}$ a.i./ml; and Phos. soil $=330 \mathrm{ml}$ phosphonate soil drench at $101 \mu \mathrm{g}$ a.i. $/ \mathrm{ml} . n=14$. 
seasonal timing of application for their effect on canker expansion. Foliar application of phosphonate is also worth investigation, but may be of limited use on mature European beech due to the large size of their canopy. Browne and Viveros (4) were able to reduce canker size on almond trees by 22 to $98 \%$ for up to 5 months after treatment, and Wicks and Hall (22) had similar success in suppressing cankers caused by $P$. cambivora in almond and cherry trees when foliar applications of the fungicide were used. Finally, it is important to note that both $P$. citricola and $P$. cactorum were reisolated from cankers regardless of treatment in the curative experiment and from most treatments in the in vitro experiment. This is similar to findings by Browne and Viveros (4), who were able to reisolate both $P$. citricola and $P$. cactorum from almond trees treated with phosphonate, fosetyl-Al, mefenoxam, or a copper-oil mixture. Fungicide treatment does not guarantee pathogen eradication, and consequently there is potential for reinfection. Mature trees should be inspected annually in autumn for new or rapidly expanding cankers. Cankers are usually readily apparent, and both pathogens are more easily isolated at that time (20). It is likely that affected trees will require several applications of phosphonate as a bark drench to limit canker expansion. An annual or biennial treatment program for several years may prove effective.

\section{ACKNOWLEDGMENTS}

Research reported herein was supported in part by grants from Agri-Chem Inc., Rainbow TreeCare Scientific Advancements Inc., and the Cornell University Agricultural Experiment Station Federal Formula Funds, Project No. NYC1536413 received from Cooperative State Research, Education and Extension Service, U.S. Department of Agriculture. Any opinions, findings, conclusions, or recommendations expressed in this publication are those of the author(s) and do not necessarily reflect the view of the U.S. Department of Agriculture.

\section{LITERATURE CITED}

1. Alvarez, L. A., Vicent, A., Soler, J. M., De la Roca, E., Bascón, J., and García-Jiménez, J. 2008. Comparison of application methods of systemic fungicides to suppress branch cankers in Clementine trees caused by Phytophthora citrophthora. Plant Dis. 92:1357-1363.

2. Bhat, R. G., Colowit, P. M., Tai, T. H., Aradhya, M. K., and Browne, G. T. 2006. Genetic and pathogenic variation in Phytophthora cactorum affecting fruit and nut crops in California. Plant Dis. 90:161-169.

3. Blaedow, R. A., Chaney, W. R., Pecknold, P. C., and Holt, H. A. 2006. Investigation of fungicidal properties of the tree growth regulator paclobutrazol to control apple scab. Arboric. Urban For. 32:67-73.

4. Browne, G. T., and Viveros, M. A. 2005. Effects of phosphonate and mefenoxam treatments on development of perennial cankers caused by two Phytophthora spp. on almond. Plant Dis. 89:241-249.

5. Coffey, M. D., and Bower, L. A. 1984. In vitro variability among isolates of six Phytophthora species in response to metalaxyl. Phytopathology 74:502-506.

6. Coffey, M. D., and Joseph, M. C. 1985. Effects of phosphorous acid and fosetyl-Al on the life cycle of Phytophthora cinnamomi and P. citricola. Phytopathology 75:1042-1046.

7. Coffey, M. D., Klure, L. J., and Bower, L. A. 1984. Variability in sensitivity to metalaxyl of isolates of Phytophthora cinnamomi and Phytophthora citricola. Phytopathology 74:417-422.

8. Copas, L., and Williams, R. R. 1987. Effect of paclobutrazol on the inoculum potential of Chondrostereum purpureum and silverleaf symptoms in cider apple cvs. Michelin and Sweet Coppin. J. Hortic. Sci. 62:287-290.

9. El-Hamalawi, Z. A., Menge, J. A., and Adams, C. J. 1995. Methods of fosetyl-Al application and phosphonate levels in avocado tissue needed to control stem canker caused by Phytophthora citricola. Plant Dis. 79:770-778.

10. Erwin, D. C., and Ribiero, O. K. 1996. Phytophthora Diseases Worldwide. American Phytopathological Society, St. Paul, MN.

11. Ferrin, D. M., and Kabashima, J. N. 1991. In vitro insensitivity to metalaxyl of isolates of Phytophthora citricola and $P$. parasitica from ornamental hosts in southern California. Plant Dis. 75:1041-1044.
12. Jackson, T. J., Burgess, T., Colquhoun, I., and Hardy, G. E. StJ. 2000. Action of the fungicide phosphite on Eucalyptus marginata inoculated with Phytophthora cinnamomi. Plant Pathol. 49:147-154

13. Jacobs, K. A., and Berg, L. C. 2000. Inhibition of fungal pathogens of woody plants by the plant growth regulator paclobutrazol. Pest Manag. Sci. 56:407-412.

14. Jung, T., Hudler, G. W., Jensen-Tracy, S. L., Griffiths, H. M., Fleischmann, F., and Osswald, W. 2005. Involvement of Phytophthora species in the decline of European beech in Europe and the USA. Mycologist 19:159-166.

15. Kanaskie, A., Hansen, E., and Sutton, W. 2005. Effects of phosphonate treatments on the growth of Phytophthora ramorum in tanoak stems. Pages 259-261 in: Proc. Sudden Oak Death Sci. Sympos. 2nd. Albany, CA. P. J. Shea and M. Haverty, eds. U.S. Dep. Agric. For. Serv. Pacific Southwest Res. Stn.

16. Matheron, M. E., and Mircetich, S. M. 1985 Control of Phytophthora root and crown rot and trunk canker in walnut with metalaxyl and fosetyl Al. Plant Dis. 69:1042-1043.

17. Nelson, A. H., Weiland, J. E., and Hudler, G. W. 2005. Geographic distribution of Phy tophthora species associated with bleeding cankers of European beech, Fagus sylvatica. Meeting of the Northeastern Division of the American Phytopathological Society, Geneva, NY. October 5-7, 2005.

18. Thomidis, T., and Elena, K. 2001. Effects of metalaxyl, fosetyl-Al, dimethomorph and cymoxanil on Phytophthora cactorum of peach tree. J. Phytopathol. 149:97-101.

19. Utkhede, R. S., and Smith, E. M. 1991. Biological and chemical treatments for control of Phytophthora crown and root rot caused by Phytophthora cactorum in a high density apple orchard. Can. J. Plant Pathol. 13:267-270.

20. Weiland, J. E., Nelson, A. H., and Hudler, G. W. 2006. Detection frequency of Phytophthora citricola and $P$. cactorum from European beech trees in New York. (Abstr.) Phytopathology $96: \mathrm{S} 121$

21. Weiland, J. E., Nelson, A. H., and Hudler, G. W. 2008. Aggressiveness of Phytophthora cactorum and Phytophthora citricola isolates on European beech and lilac. (Abstr.) Phytopathology 98:S168.

22. Wicks, T. J., and Hall, B. 1990. Control of Phytophthora canker with phosphonate in artificially inoculated almond and cherry trees. Aust. J. Exp. Agric. 30:413-420. 